\title{
ARGUMENTAATIO MONITIETEISEN OPETUKSEN EDELLYTYKSENÄ
}

\begin{abstract}
Monitieteisyys, poikkitieteisyys, tieteidenvälisyys ja tieteiden välisten rajojen tahi raja-aitojen ylittäminen ovat ajan hengen mukaisia käsitteitä opetuksen kehittämisessä. Pohdimme artikkelissamme monitieteisyyden problematiikkaa ja käsitettä sekä monitieteisen opetuksen elementtejä kahden opintojakson avulla. Kirjoittajille monitieteinen opetus avautuu argumentaation, yhteistoiminnan sekä tiedonhankinnan ja -hallinnan taitojen kautta. Esittelemme kaksi opintojaksoa, joista toinen perehdyttää argumentaation ja retoriikan perusteisiin ja toinen teledemokratian ilmiöön. Käytämme näitä kahta sisällöltään ja toteutustavaltaan erilaista opintojaksoa esimerkkinä siitä, millaista etua monitieteisestä opetuksesta voi olla opiskelijoille ja opettajille.
\end{abstract}

\section{EEVAAARNIO, MIKKO JÄKÄLÄ JA JOHN PAJUNEN}

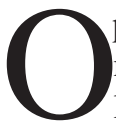
pintojaksojen suunnittelua aloittaessamme näimme monitieteisyyden liittyvän lähinnä opetuksen sisältöön ja sisältövalintoihin. Pian kävi kuitenkin ilmeiseksi, että monitieteinen opetus on käytännössä enemmän kuin eri tieteenalojen näkökulmien esittämistä ja yhdistämistä. Se alkoi edellyttää sisällön lisäksi huomion kiinnittämistä vuorovaikutukseen ja siinä erityisesti argumentaatioon ja oppimisen yhteistoiminnallisuuteen. Tämä näennäisesti itsestään selvä havainto johti yliopisto-opetuksen kehittämishankkeeseen ja näiden opintojaksojen vakiinnuttamiseen tieteenalojen rajat ylittävään opinto-ohjelmaan. Artikkelin päätteeksi koostamme kokemuksiamme ja pohdimme havaintoja monivuotisen ja monitieteisen opintojakson järjestämistä.

\section{MONITIETEISYYSOPETUKSEN ELEMENTIT}

Monitieteisyys on käsite, jonka sisältö vaihtelee määrittelijänsä mukaan. Monitieteisyyttä voivat olla esimerkiksi seminaarit, joissa eri tieteenalojen edustajia kootaan yhteen saman teeman ympärille, opetuksellinen rajojen ylittäminen kuten dialogiluennointi, vierailevien luennoitsijoiden käyttö, monitieteisten koulutusohjelmien suunnittelu ja toteuttaminen sekä eri tieteenaloja yh-

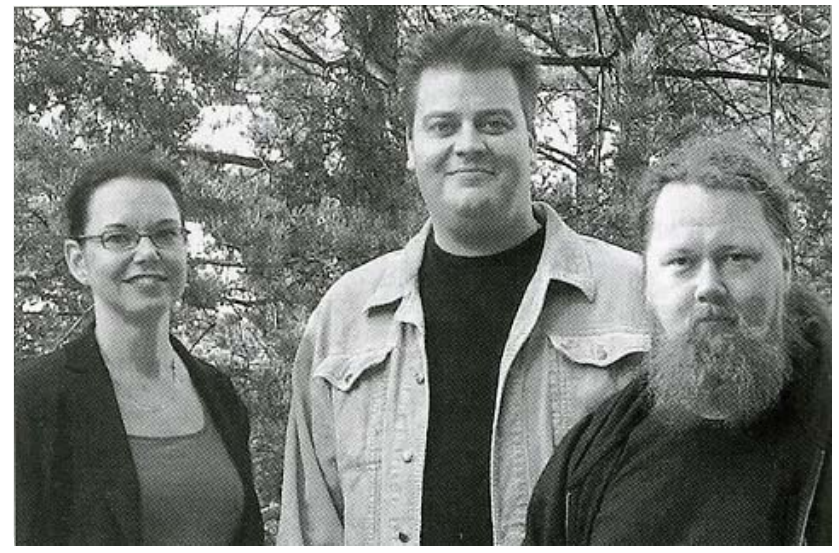

Eeva Aarnio, Mikko Jäkälä ja John Pajunen

distävä tutkimus ja siihen liittyvä opetus. Vuonna 2001 käynnistynyt Suomen Akatemian Life as Learning -tutkimusohjelma (Life 2001) pyrkii edistämään tutkimuksen ja opetuksen monitieteisyyttä ja yhteistyötä. Hankkeen käytännöllisenä tavoitteena on tuottaa soveltavaa monitieteistä tutkimustietoa oppimisen ja opettamisen eri osaalueilta. Monitieteisen yliopisto-opetuksen määrän arviointi riippuu siitä, mitä monitieteisenä pidetään. Monitieteiseksi opetukseksi tulee luokitelluksi opetusta, jossa monitieteisyys muodostuu sisällöllisistä, menetelmällisistä tai rakenteel- 
lisista valinnoista. Meille monitieteisyyden käsite on tarkentunut tutkimusyhteistyön sekä siitä käynnistyneen opetuksen suunnittelu-, kehittämis- ja toteutusyhteistyön kontekstissa.

Olemme suunnitelleet Jyväskylän yliopistossa kaksi kahden opintoviikon laajuista monitieteistä opintojaksoa, joihin niin opettajat, opiskelijat kuin sisällötkin tulevat eri tieteenaloilta. Argumentaation ja retoriikan perusteet on vuodesta $1999 \mathrm{Jy}-$ väskylän yliopistossa vuosittain järjestetty 5 tiedekunnan ja 20 oppiaineen yhteinen opintojakso. Teledemokratia-workshop järjestettiin ensimmäisen kerran vuonna 2000. Opintojaksolle osallistuu valtio-opin ja tietojärjestelmätieteen opiskelijoita. Opintojaksojen opettajat ovat tehneet monitieteistä tutkimusyhteistyötä kolmessa hankkeessa, joista yksi keskittyy poliittiseen retoriikkaan, toinen poliittisiin tietotaitoihin ja tekniikoihin ja kolmas opetuksen laadun kehittämiseen. Kaikkineen hankkeissa on ollut mukana tutkivia opettajia valtio-opista, naistutkimuksesta, viestintätieteistä, multimediasta, tietojärjestelmätieteestä, kasvatustieteestä ja filosofiasta.

Hankkeissa hioutui opettajien yksittäisistä näkökulmista vähitellen monitieteinen. Opettajat ovat esimerkiksi käsitteellistäneet ja etsineet yhteistä kieltä työn alla olleeseen teemaan keskusteluissaan, seminaareissaan ja tutkimuksessaan. Yhdistävä tekijä on argumentaatio sekä argumentaatio- ja viestintätaidot, jotka ovat monitieteisyyden edellytyksiä. Tätä haluttiin välittää opiskelijoille vuorovaikutteisuuteen ja omia näkemyksiään kyseenalaistamaan kannustavassa oppimisympäristössä.

Monitieteisen opetuksen rakentamisessa on mielestämme oleellista ymmärtää tieteellisten väittämien ja perustelujen rakenne ja hahmottaa oman tieteenalansa argumentaation erityispiirteet ja vaatimukset. Argumentti tarkoittaa väitteen ja perustelujen sekä taustaoletusten muodostama kokonaisuutta, jolla argumentoija pyrkii vakuuttamaan yleisönsä väitteidensä hyväksyttävyydestä antamillaan perusteilla. Argumentaatio on väitteiden ja vastaväitteiden esittämistä sekä näiden perustelemista. Argumentaatiotaito merkitsee siis kykyä esittää perusteltuja väitteitä sekä analysoida ja arvioida kriittisesti esitettyjä väitteitä. ${ }^{1}$

Argumentaatiotaidot mahdollistavat yhteistoiminnan. Yhteistoiminta on puolestaan edellytys monitieteisen opetuksen syntymiselle. Monitieteinen opetus ei ole meille yksinomaan eri tieteenalojen tiedon tai näkökulmien esittämistä, vaan eri oppialojen edustajien dialogissa rakentuu tieto aidosti monitieteisesti.

Argumentaatio- ja analyysitaidot tulee mielestämme mieltää koulutetun asiantuntijan yleisvalmiuksiksi. Argumentaatiotaitojen opetusta puoltaa ensinnäkin se, että tieteellinen kirjallisuus ja oppikirjat sisältävät väitteitä ja väitteiden perusteluja. Tieto on myös yhä sirpaleisempaan ja hajanaisempaa, mikä korostaa tiedonhankinnan ja valinnan taitoja.

Yliopisto-opetuksen tavoitteena on perinteisen tieteellis-kriittisen asenteen omaavien kansalaisten lisäksi kouluttaa kansalaisyhteiskuntaa ymmärtäviä kehittäjiä. Tieteellisen tiedon soveltaminen työelämässä edellyttää taitoa analysoida ja arvioida paitsi omaa tieteenalaa, myös sen yhteyttä yhteiskunnan osa-alueisiin. Soveltamiskyvyn kehittämistä ajatellen on tarkoituksenmukaista rakentaa oppimistilanteita sellaisiksi, että opiskelijat joutuvat paneutumaan perustelemiseen myös oman tieteenalansa ulkopuolella ilman jaettua ymmärrystä tai tietoa taustaoletuksista. Tämä on usein haastavampaa kuin oman tieteenalan edustajille argumentoiminen, sillä saman tieteenalan edustajat voivat helpommin jakaa yhteisen kielen, käsitteet ja näkökulmat tarkastella ilmiötä.

\section{ARGUMENTAATION JA RETORIIKAN PERUSTEET}

Argumentaation ja retoriikan perusteet -opintojaksolla esitellään argumentaatioteorian ja retoriikan peruskäsitteet. Sen tavoitteena on kehittää opiskelijan valmiuksia analysoida ja tuottaa tieteellisiä tekstejä ja puheenvuoroja. Opintojaksolla esitellään modernin argumentaatioteorian perusteet: argumentaation yleinen kuvaus, argumentaatiota käytännössä, menetelmä tekstien analysoimiseksi, välineet argumenttien arvioimiseksi sekä klassisen retoriikan peruskäsitteistöä ja modernia retoriikan teoriaa.

Argumentaatioteoriaa sovelletaan erimuotoisten dokumenttien analysoimiseen ja arvioimiseen. Arviointi kohdistetaan dokumenttien tuottamisen vaikuttimiin, niiden luotettavuuteen ja argumenttien pätevyyteen: kuka viestii kenelle, miksi, miten ja millä tavoitteilla. Esimerkiksi globalisaatiota käsittelevistä www-sivuista kriittinen lukija tunnistaa muun muassa tekstien yhteiskunnallisia ja taloudellisia sidoksia ja sisällöntuottajien vaikuttimia. Harjoituksissa pyritäänkin löytämään 
dokumentin vaikuttamisen keinot. Kriittinen lukija ei suhtaudu dokumentteihin yksioikoisesti eikä näe tieteellistäkään tietoa monoliittisena faktakokoelmana, joka tuotetaan ongelmattomasti havainnoimalla maailmaa.

Tiedon syvempi ymmärtäminen vaatii perustelemisen teoreettisten ulottuvuuksien ymmärtämistä. Filosofisesta ja teoreettisesta perspektiivistä katsoen on keskeistä hahmottaa tiedon luonnetta. Tämä merkitsee tutustumista tiedon filosofian perusteisiin, sillä väittämät voivat olla luonteeltaan teoreettisia tai empiirisiä, ne voivat kohdistua fyysiseen, psyykkiseen tai sosiaaliseen todellisuuteen. Eri tiedon alueilla on erilaisia lähtökohtia ja perustelutyyppejä.

\section{A} rgumentaation ja retoriikan perusteet opintojakso koostuu viidestä osasta: lu ennoista, opettajajohtoisesta oppiainekohtaisesta pienryhmätyöskentelystä, opiskelijoiden itsenäisestä ryhmätyöskentelystä, seminaarista ja tentistä. Argumentaation ja retoriikan teorian perusteet esitellään yhteisenä luento-opetuksena, jonka luennoi filosofian opettaja. Luentomoniste tiivistää luentojen sisällön ja auttaa opiskelijoita jäsentämään kokonaisuutta. Moniste kiinnittää myös pienryhmäohjaajat luento-osan sisältöihin ja luennon etenemisjärjestykseen. Joskin useimmiten pienryhmäohjaajat ovat innostuneet itsekin osallistumaan luennolle ja oppimaan uutta. Erityinen haaste johdantoluennon opettajalle on osallistujien heterogeenisuus. Opiskelijat tulevat useasta tiedekunnasta ja lukuisista oppiaineista. Luennolla istuvat vierekkäin ensimmäisen vuoden ja opintojensa loppuvaiheessa olevat opiskelijat. Oppiaineesta riippuen opintojakso voi olla yleisopintoja, perusopintoja, aineopintoja tai jatko-opintoja. Halu taitaa argumentaatiota yhdistää kuitenkin kaikkia eri tieteenalojen osallistujia.

Luentojen tavoitteena on nivoa argumentaatioteoria monitieteisessä ympäristössä osallistujien arkipäivään. Ennen luento-osuutta luennoitsija keskustelee eri oppiaineiden pienryhmäohjaajien kanssa. Yhdessä he hakevat tyypillisiä arkipäivän esimerkkejä, joiden avulla argumentaatioteoriaa havainnollistetaan luennolla. Luennoitsija nostaa tutuista asioista esiin niiden argumentatiivisen ulottuvuuden. Eri tieteenalojen näkökulmasta esimerkiksi www-sivuja analysoitaessa huomio kiinnittyy eri asioihin. Tietojärjestelmätieteilijän huomio kiinnittyy ensimmäisenä sivun tekniseen toteutukseen esimerkiksi käytettävyyteen, sivuilla navigointiin ja informaation esittämiseen. Viestintätieteilijä katsoo sivuja vaikuttamisen ja sanoman välittämisen näkökulmasta, kun valtio-oppinut kiinnittää huomionsa esimerkiksi tekstin valtarakenteisiin tai yleisökonstruktioihin. Filosofian opiskelija lähestyy sivuja luontevimmin perustelemisen rakenteiden tarkastelun kautta. Kun erilaiset näkökulmat samaan ilmiöön tehdään näkyväksi, opiskelijoilla on mahdollisuus tunnistaa omia vakiintuneita näkökulmiaan. Samalla on mahdollista ymmärtää esitettyjen näkökulmien yhtäläinen mielekkyys. Vaihtoehtoiset näkökulmat lisäävät opiskelijoiden erilaisuuden havaitsemisen taitoa ja sietokykyä, mikä tuottaa hyvää pohjaa yhteistoiminnalle ja yhdessä oppimiselle.

Argumentaation ja retoriikan perusteet -opintojakson toisessa osiossa opiskelijat osallistuvat oman tieteenalansa opettajan johdolla pienryhmätyöskentelyyn. Eri tieteenalojen pienryhmissä työskentelytavat ja tavoitteet vaihtelevat. Samoin argumentaatioteorian merkitys avautuu eri oppiaineille eri tavoin. Joillakin aloilla teoriaan suhtaudutaan tutkimusmenetelmänä, toisilla aloilla se voi saada hyvinkin käytännöllisen merkityksen, jopa argumentoinnin perusteiden opiskelu saattaa tulla kyseeseen. Pienryhmien monimuotoisuus sopii erittäin luontevasti monen eri tieteenalan näkökulmille rakentuvalle opintojaksolle. Pienryhmät palaavat luennolla käsiteltyihin asioihin ja työstävät niitä yhdessä oman tieteenalan käytännön harjoitusten avulla. Pienryhmätyöskentely tukee opiskelijaa tiedon jäsentämisessä ja tietokokonaisuuden muodostamisessa oman tieteenalan asiayhteyksissä. Pienryhmät voivat esimerkiksi analysoida yleisönosastokirjoituksia hyvinkin eri näkökulmista. Kasvatustieteissä voidaan analysoida opetusta tai koulutusta koskevien kirjoitusten argumentaatiorakenteita, -tyyppejä ja -tapoja. Sosiologian opiskelijat voivat kohdistaa huomionsa kirjoituksien eksplisiittisiin ja implisiittisiin sosiaalisiin normeihin. Digitaalisen median ja multimedian pienryhmässä voidaan pohtia julkaisumuodon ja kanavan vaikutusta kirjoitusten argumentaatioon ja sisällöntulkintaan. Pienryhmässä ohjaaja on keskusteluttaja, tukija ja fasilitaattori.

Kolmannessa osiossa opiskelijat työskentelevät itsenäisinä ryhminä. He valmistavat luentojen aihepiireihin liittyvän esityksen päätösseminaariin. Tämä osio perustuu opiskelijoiden kes- 
kinäiselle yhteistoiminnalle. He suunnittelevat esityksen, jolla he pyrkivät vakuuttamaan muut seminaariin osallistuvat opiskelijat ja voivat osoittaa taitonsa käyttää opittua. Opiskelijaryhmät valitsevat oman oppiaineensa kannalta oleellisen näkökulman argumentaatioon tai argumentaatioteoriaan. He valmistelevat esityksen, jonka muoto on rajoitettu vain kestoltaan. Usein valmistelutyöhön liittyy tiedonhaun ja tiedon valitsemisen harjoittelemista. Seminaariesitys voi olla esitelmä, ryhmäpuheenvuoro, video tai vaikkapa dramatisointi. Opiskelijat työstävät yhdessä keskustellen luentojen sisältöjä, jolloin argumentaatioteorian ja oman oppiaineen yhteys nivoutuu kokonaisuudeksi.

Neljäs osio, seminaari, on täysin opiskelijavetoinen. Opiskelijoiden esityksissä konkretisoituu, kuinka asiasisältö tulee esittää tietylle yleisölle. Kolmannen ja neljännen osion johtoteemaksi voi muotoilla kysymyksen, miten vakuutan yleisön kannastani. Esimerkiksi liikuntatieteilijöistä koostunut pienryhmä rekonstruoi Lahden vuoden 2001 MM-kisojen dopingkeskustelun. Ryhmäläisten rooleina olivat naishiihtäjä, mieshiihtäjä, lehdistön edustaja, valmentaja, hiihtoliiton edustaja, suomalainen poliitikko ja joukkueen lääkäri. Dramatisoinnissa havainnollistettiin keskustelun argumentatiiviset ulottuvuudet toimijoiden eri roolien ja vaikuttimien näkökulmasta. Esityksen aiheen ajankohtaisuus takasi sen, että yleisö tunsi tilanteen ja taustat tv:n ja lehtien kautta. Yleisön hyvin tuntema mediakeskustelu jäsentyi uudelleen argumentaatioteorian kautta. Yksi tarina syveni seitsemäksi erilaiseksi tarinaksi argumentoijasta riippuen.

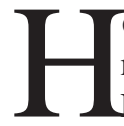

eterogeenisen yleisön vakuuttaminen seminaarissa on erittäin vaativa tehtävä. Esitykset, jotka liittyvät konkreettisiin ilmiöihin ja luovat siihen argumentaatioteorian avulla tieteenalansa näkökulman, avautuvat ja vakuuttavat yleisön helpommin kuin esitykset, joilla ei ole kiinnekohtaa kuulijoiden arkeen. Ongelmalliseksi ovat osoittautuneet myös sellaiset esitykset, jotka lähinnä kuvaavat ja toistavat luennolla kuultua. Tällöin lienee kyse sitä, ettei opittua osattu vielä soveltaa käytäntöön. Esityksen pitäminen ohjaa pohtimaan yhteisten luentojen ja pienryhmätyöskentelyjen sisältöjä, jolloin ne eivät jää irrallisiksi tiedon sirpaleiksi, vaan yhdistyvät teoreettisen tiedon ja konkreettisen taidon kokonaisuuden ymmärtämiseksi.
Seminaarissa keskustellaan ja kuulijat esittävät myös kysymyksiä ja kommentteja esiintyjille. Samoin pienryhmävetäjät kommentoivat esityksiä ja tarvittaessa pyytävät pienryhmiä argumentoimaan syvällisemmin teemaansa ja ratkaisujaan. Esityksen tieteelliset perusteet ja niihin liittyvä argumentointi on aloittanut eri oppiaineiden pienryhmävetäjien välisen kiivaankin debatin. Opiskelijapalautteiden mukaan seminaarin vahvuus on se, että osallistujat näkevät argumentaatioilmiön teoreettiset ja käytännölliset ulottuvuudet eri oppiaineiden näkökulmista.

Opintojakson viides osio on tentti. Tentin luonne on kokoava ja sen tavoitteena on saada opiskelijat kertaamaan opintojakson keskeisiä teemoja ja tuottamaan selkeä argumentatiivinen essee opintojakson sisältöjen hengessä. Opintojakson eri osiot on suunniteltu edistämään oppimista siten, että argumentaation filosofis-teoreettinen ja käytännön taso muodostavat eheän kokonaisuuden. Kaikki opintojakson osiot ovat tähdänneet argumentaation ja retoriikan perusteiden ymmärryksen tuottamiseen.

Opettajien ja opettamisen näkökulmasta argumentaation ja retoriikan perusteet -opintojakso avaa uusia näkökulmia argumentaatioteoriaan, mitä he voivat hyödyntää suoraan omassa työssään. Opintojakso voi antaa todellisen mahdollisuuden tutustua muihin mukana oleviin tieteenaloihin ja niiden edustajiin, joihin muuten ei ehkä olisi kontaktia tai kiinnostusta arjessa. Opettajille avautuu yliopistokulttuurille epätyypillinen tilaisuus vaihtaa näkemyksiä argumentaatiosta, oppiaineista ja opetuksesta kollegoiden kanssa. Toteutuakseen tämä edellyttää, että pienryhmien vetäjät altistavat itsensä epävarmuudelle. Monet pienryhmävetäjät osallistuvat itsekin johdantoluennoille ja kertoivat myöhemmin huomanneensa puutteita omissa argumentaatioteorian tiedoissaan. Ennen seuraavaa toteutuskertaa pienryhmävetäjät esittelevät ja kommentoivat toisilleen pienryhmien opetussuunnitelmia. Yhteiset tapaamiset alentavat kynnystä yhteydenpitoon opetuksen aikana ja kollegaan on helppo ottaa yhteyttä esimerkiksi sähköpostitse. Pienryhmäohjaajat ovat kertoneet ottaneensa mallia toisten hyvistä käytännöistä vetää pienryhmiä ja harjoituksia. Käytännössä opettajille on avautunut mahdollisuuksia nähdä, kuinka sama tavoite voidaan saavuttaa erilaisilla ratkaisuilla. Opintojakson päätyttyä pienryhmäohjaajat arvioivat opintojakson toteutusta ja lopputapaamisessa 


\begin{tabular}{|llll|}
\hline Osio & Työskentelymuoto & Toimija & Tavoite \\
\hline Aloituskeskustelu & $\begin{array}{l}\text { keskustelu ja tehtävien } \\
\text { luonnostelu }\end{array}$ & $\begin{array}{l}\text { opettaja ja pien- } \\
\text { ryhmäohjaajat }\end{array}$ & $\begin{array}{l}\text { monitieteisen sisällön } \\
\text { tuottami }\end{array}$ \\
$\begin{array}{l}\text { Johdantoluennot } \\
\text { Oppiainekohtaiset } \\
\text { pienryhmät }\end{array}$ & luennot & opettaja ja opiskelijat & teorian esittely \\
$\begin{array}{l}\text { Opiskelijoiden } \\
\text { itsenäinen työskentely }\end{array}$ & ryhmätyö & $\begin{array}{l}\text { opiskelijat ja pien- } \\
\text { ryhmäohjaajat }\end{array}$ & soveltamisen harjoittelu \\
$\begin{array}{l}\text { Seminaari } \\
\text { Tentti }\end{array}$ & seminaariesitykset & $\begin{array}{l}\text { opiskelijat } \\
\text { opiskelijat, opettaja, } \\
\text { pienryhmäohjaajat } \\
\text { opiskelijat }\end{array}$ & $\begin{array}{l}\text { opitun ulkoistaminen } \\
\text { jammentointi } \\
\text { kertaaminen ja } \\
\text { reflektointi }\end{array}$ \\
Palautekeskustelu & keskustelu & opettaja ja pien- & arviointi ja kehittäminen \\
& & ryhmäohjaajat & \\
\hline
\end{tabular}

käydään läpi opiskelijapalaute ja arvioidaan opintojaksolla käytettyjä menetelmiä. Lopputapaamisessa käynnistetään opintojakson seuraavan toteutuskerran valmistelu.

\section{TELEDEMOKRATIA-WORKSHOP}

Teledemokratian käsite ei ole yksiselitteinen. Tämän vuoksi teledemokratiakeskustelua voidaan käydä mitä erilaisimmista teemoista ${ }^{1}$ Teledemokratiaa on käsitelty esimerkiksi elektronisen demokratian, digitaalisen demokratian ja kyberdemokratian käsitteiden avulla. Hagen (1997) on määritellyt eri käsitteiden sisältöjä ja suhteita toisiinsa elektronisen demokratian typologian avulla (ks. myös Watson \& Mundy 2001). Ensimmäiset teledemokratiakokeilut tarkoittivat teknologian hyödyntämistä kansalaisten osallistumisen ja vaikutusmahdollisuuksien lisääjänä. Teknologiaa testattiin esimerkiksi elektronisissa kaupunkikokouksissa ja etä-äänestämisessä. (Becker \& Slaton 2000; Wilhelm 2000.) Tämän jälkeen kokeiluissa käytettiin radion, puhelimen ja television lisäksi myös tietotekniikkaa ja tietokoneita. Teknologian käytön tavoitteena oli rakentaa suoria vaikutuskanavia.

Teledemokratiakeskusteluissa pohditaan erityisesti viestintäteknologioiden suhdetta demokratiaan (mm. Fishkin 1991; Masuda 1981). Taustaoletuksena on usein se, että teknologia ratkaisee perinteiseen institutionaaliseen politiikkaan ja edustajuuteen liittyviä ongelmia. Teledemokratia mahdollistaa myös poliittisen tiedon ja mielipiteiden nykyistä tehokkaamman välittymisen niin perinteisten kuin uudentyyppisten, jopa virtuaalisten, poliittisten ryhmien sisällä ja välillä. Eräiden käsitysten mukaan teknologiaa on otettu käyttöön, jotta demokraattisten arvojen - kuten tasa-arvon, saavutettavuuden, moniarvoisuuden - toteuttamista voitaisiin helpottaa ja näin saavuttaa demokraattisempi ja oikeudenmukaisempi yhteiskunta. (Watson, Akselsen, Evjemo, \& Aarsæther 1999; Wilhelm 2000.) Teledemokratia nähdään foorumina keskustelulle ja olemassa olevien järjestelmien ja vakiintuneiden käsitysten kyseenalaistamiselle. Teledemokratialle on luonteenomaista vaikuttaminen. Vaikuttamalla tavoitellaan muutosta, ajetaan etuja ja nostetaan esiin vaihtoehtoja.

$\mathrm{T}$ leledemokratia-workshopissa tutustutaan teledemokratian käsitteeseen, teledemokratian historiaan sekä teledemokratian sovellusalueisiin käytännön esimerkkien avulla. Yhteiskuntatieteissä teledemokratiaan liitetään usein demokratiateoreettisia odotuksia, muun muassa kansalaisten aktivoiminen, syrjäytymisen ehkäiseminen sekä aika- ja paikkariippuvuuden vähentäminen. Tietojärjestelmätiede puolestaan lähestyy teledemokratiaa esimerkiksi tietojärjestelmien suunnittelun ja kehittämisen, dokumenttien hallinnan, elektronisen julkaisemisen ja ohjelmis- 
totuotannon näkökulmista. Teledemokratia workshop -opintojakson etuna onkin, että opiskelijat tulevat nimenomaan informaatioteknologian tiedekunnasta ja yhteiskuntatieteellisestä tiedekunnasta. Opintojakson osallistujaryhmä on rajattu pieneksi, ja opintojaksoa vetävät tietokonevälitteisen viestinnän ja valtio-opin opettajat tiiminä. Molemmat opettajat ovat kaikissa istunnoissa aktiivisia toimijoita. Opintojaksolla käytetään elektronista oppimisympäristöä, johon on sijoitettu perustiedot opintojaksosta, kuten kurssikuvaus, aikataulut, ohjelma ja ohjeet opintojakson suorittamisesta. Oppimisympäristössä ovat myös opintojakson oppimistehtävät, elektroninen materiaali, kirjallisuusluettelo sekä opintojakson palautelomake. Oppimisympäristöä käytetään ilmoitustauluna ja keskustelualustana sekä kaikkien oppimistehtävien jakamiseen osallistujien kesken sähköisessä muodossa. Opintojakson aluksi opiskelijat perehdytetään oppimisympäristöön ja sen käyttöön. Vaikka osa heistä käyttää elektronista oppimisympäristöä ensimmäisen kerran, käyttö vaikuttaa yllättävänkin sujuvalta ja ongelmattomalta. Tämä ei kuitenkaan tarkoita sitä, että kaikilla osallistujilla olisi erinomaiset tietotekniset taidot tai edes halua niiden hankkimiseen. Toisaalta enemmistö opiskelijoista pitää elektronisen oppimisympäristön käyttöä luontevana osana opintojaksoa ja sen oppimistavoitteita.

Teledemokratia workshop -opintojakson tavoitteena on ensinnäkin harjaannuttaa opiskelijoita teledemokratiasta käytävän tieteellisen keskustelun ja toisaalta internetissä olevien teledemokratiapalvelujen analysoinnissa ja arvioinnissa. Arviointiprosessi on luonteeltaan kehämäinen siten, että kuvaus, analyysi ja arviointi vuorottelevat. Arvioinnin avulla pyritään muodostamaan kokonaisnäkemys erilaisten dokumenttien tiedon muodostumisen mekanismeista, siitä mikä on oleellista tietoa ja informaatiota vaativissa valintatilanteissa. Toiseksi opintojakson tavoitteena on se, että opiskelijat oppivat käsitteellistämään yhdessä teledemokratian ilmiötä ja jäsentämään omaa näkemystään siitä. Edelleen tavoitellaan sitä, että opiskelijat pystyvät itsenäisesti tunnistamaan ja muodostamaan merkityksellisiä kysymyksiä teledemokratian ilmiöstä.

$\mathrm{M}$ onitieteinen opetus näkyy käytännössä yhdessä tekemisenä. Aineistoja esimerkkejä on molemmilta tieteenaloilta, opettajien painotukset juontuvat oman tieteen- alan traditioista ja terminologiassa, jopa kielenkäytössä on eroja. Workshopissa opettajat kuitenkin aktiivisesti hakevat ja työstävät dialogissa käsiteltävän ilmiön yhteistä näkökulmaa ja kieltä. Opettajat eivät missään vaiheessa pyri peittämään näkökulma- tai käsite-erojaan, vaan myös opiskelijat haastetaan kyseenalaistamaan oppiainesidonnaisia vakiintuneita käsityksiään. Opettajat tukevat oppimista auttaen ongelman rajauksessa ja jaottelussa, virittäen ongelman syvempään tarkasteluun ja tarjoten malleja ongelman käsittelyyn ja johtopäätöksien tekoon. Workshopissa kaikki osallistujat ovat vastuussa siitä, että kulloisillekin esiintyjille esitetään kysymyksiä ja kommentteja sekä vaateita tarkemmille perusteluille. Tämän lisäksi osallistujat etsivät yhdessä käytännön esimerkkejä ja analogioita teledemokratiailmiön eri ulottuvuuksista. Keskustelua ja yhteistyötä tuetaan harjoituksilla ja puheenvuoroja ohjaavalla kierrosmenettelyllä.

Opintojakso korostaa vuorovaikutusta ja aktiivista osallistumista keskusteluihin. Keskustelutavoite on opintojakson haavoittuvin kohta. Syvällinen keskustelu edellyttää omaehtoista tutustumista käsiteltävään ilmiöön ja käytössä olevaan materiaaliin, joka on luonteeltaan sellaista, että eri oppialoilla kiinnitetään huomio eri asioihin. Ilman valmistautumista keskustelu jää opiskelijapalautteen mukaan opiskelijoita itseäänkin häiritsevälle tasolle. Keskustelu alkaa toimia, kun opiskelija ymmärtää vastuunsa ryhmän oppimisen tuloksista. Jokaisen toteutuskerran palaute on viitannut siihen, että aktiivisen roolin ottaminen on osalle opiskelijoista edelleen hyvin haastavaa ja uutta. Vanhat luennoilla tai seminaareissa opitut toimintamallit on korvattava aktiivisella oman roolin ottamisella. Sekä opettajat että opiskelijat esittävät kysymyksiä, antavat palautetta ja tukevat keskustelulla asioiden välisten yhteyksien löytämistä. Erilaiset asiantuntemuksen alueet, näkökulmat ja mielenkiinnon kohteet sekä erilainen osallistuminen yhteisön toimintaan tarjoavat opiskelijoille erilaisia toimintatapoja sekä mahdollisuuden uuden oppimiseen. (Katso. esim. Malinen 2000, Vygotskij 1978, Rogoff 1990.)

Teledemokratia-workshop koostuu neljästä osiosta: johdantoluento, artikkelipohjainen ryhmätyöskentely ja artikkelin esittely, ryhmän perehtymisalueen valinta ja työstäminen sekä ryhmätyön esitteleminen. Teledemokratia-workshop alkaa teledemokratian käsitteen hahmottamisella eri tieteenalojen näkökulmista. Aluksi opettajat 
esittelevät yhdessä teledemokratian ilmiön moniulotteisuutta ja ongelmakohtia, teledemokratiatutkimusta, ilmiön lähestymistapoja sekä teoreettisesta keskustelua oman tieteenalansa näkökulmista. Tämän jälkeen opiskelijat etsivät internetistä palvelun, joka jollakin perusteella liittyy teledemokratiaan. He kuvaavat löytämänsä palvelun toisilleen. Tämän lyhyen teoreettisen katsauksen ja itsenäisen kokeilun tavoitteena on havahduttaa opiskelija huomaamaan yhtäältä teledemokratian ilmiön kohtalainen tuttuus ja toisaalta tutkimuksen yhteys näihin käytännön sovelluksiin. Odotus sille, että johdantoluennot antaisivat kattavan kuvan teledemokratiasta, on käsin kosketeltava. Se ei kuitenkaan ole johdannon tavoite. Osaa opiskelijoista tämä palautteen mukaan hämmentää, osaa turhauttaa ja osaa houkuttaa.

Toisen osion aluksi opiskelijat tutustuvat opintojaksolle koostettuun monitieteiseen artikkelipakettiin, joka syventää näkökulmia workshopin teemoihin. Kirjallisuuspaketti ei auta jäsentämään teemaa, vaan sen tarkoituksena on edelleen provosoida opiskelijoita ymmärtämään ilmiön sirpaleisuus, monitahoisuus, ristiriitaisuus ja kiistanalaisuus. Artikkelityöskentelyssä opiskelijaryhmä valitsee yhden artikkeleista arviotavaksi ja muille esiteltäväksi. Kiinnostaviksi aiheiksi ovat osoittautuneet esimerkiksi valtion harjoittama internetin suodattaminen ja sensuuri, elektroninen äänestäminen ja internet kaupunginosien yhteisöllisyyden uudentyyppisenä mahdollistajana. Keskeistä valitun artikkelin työstämisessä ja esittelyssä muille opiskelijoille on valitun näkökulman perusteltu tiivistäminen, eritteleminen ja arvioiminen sekä kirjallisesti että suullisesti.

Workshop-työskentelyyn on sisäänrakennettu oletus siitä, että kaikki osallistujat valmistautuvat keskusteluun tutustumalla materiaaliin ennalta. Tämä vaatii opiskelijoilta sitoutumista. Se, että artikkeleihin ei ole tutustuttu ennalta, näyttäytyy workshopissa korostettuina arkikokemuksina materiaalin tarjoamien teoreettisten näkökulmien sijasta. Parhaimmillaan opiskelijat pystyvät yhdistämään useiden artikkelien tietoja esityksessään ja muiden esitysten kommenteissaan. Esitykset toimivat pohjana teemoja työstävälle ryhmäkeskustelulle, johon opettajat osallistuvat ryhmän jäseninä. Usein keskusteluissa opettajat nostavat esiin keskenäänkin eriäviä näkemyksiä ja perusteluja. Opiskelijapalautteen mukaan monitieteinen oppimistilanne näkyy selkeimmin opettajien välisessä debatissa. Opiskelijoiden mielestä on ollut mielenkiintoista se, että opettajat esittävät tiettyyn teemaan kilpailevat näkökulmat, toisinaan jopa kiistävät kuulemansa tai kamppailevat siitä, mikä teemassa on tieteellisesti kiinnostavaa tai keskeistä. Opiskelijat ovat kiinnittäneet huomiota myös kuuntelemisen merkitykseen havaitessaan opettajien argumentoivan toisiaan kuuntelematta. Opettajien oman argumentaation puutteet ja ansiot ovat saattaneet kannustaa myös opiskelijoita esittämään ja testaamaan omia näkemyksiään julkisesti.

Kolmannessa osiossa opiskelijaparit valitsevat artikkelikeskustelujen ohjaamana itseään kiinnostavan teeman esseensä aiheeksi. Esseen työstövaiheessa esseen aihe, alustava sisältöidea ja lähdeaineisto esitellään perustelujen kera muulle ryhmälle. Ryhmä ja opettajat antavat suunnitelmasta palautetta ja kanssaideoivat sitä eteenpäin. Arvioiva keskustelu voi virittää uusien näkökulmien havaitsemiseen tai lisätiedon etsimiseen. Toisaalta sen tavoitteena on myös rajata ideaa, jotta työstettävästä teemasta saadaan muotoutumaan järkevä ja hyödyllinen kokonaisuus.

Yleisen keskustelun lisäksi opiskelijoilla on mahdollisuus keskustella aiheestaan tai saada palautetta tekstistään opintojakson ohjausklinikalla. Ohjausklinikka on alun perin suunniteltu tukemaan esseen kirjoitusprosessia. Klinikalla opiskelijalla on mahdollisuus saada henkilökohtaista ohjausta esseen suunnitelmasta, rajauksista tai valinnoista opintojakson opettajilta. Klinikka tarjoaa mahdollisuuden vapaamuotoiseen keskusteluun ja palautteen saamiseen keskeneräisestä työstä. On näyttänyt kuitenkin siltä, että klinikalle tulevat kirjoitusprosessissaan jo hyvin edistyneet ja asiassaan varmat opiskelijat ennen kaikkea testaamaan ajatuksiaan, eivätkä niinkään kirjoittamiseen liittyvien ongelmien takia. Tästä syystä klinikalla käydyt keskustelut ovat olleet syvällisiä. Toisaalta opettajien näkökulmasta on kuitenkin haasteellista saada ne opiskelijat tulemaan vapaaehtoiselle klinikalle, jotka tarvitsisivat eniten ohjausta.

Neljännessä osiossa opiskelijapari esittelee teemansa uudelleen ryhmälle. Puheenvuoron tavoitteena on, että opiskelijat osoittavat ymmärtävänsä teledemokratian ilmiötä ja pystyvät käyttämään käytännössä oppimaansa. Esseet ovat käsitelleet esimerkiksi kansalaisten vaikutusmahdollisuuksia kuntien verkkosivuilla, anarkismia tietoverkoissa ja institutionaalisen politiikan uusia toimintatapoja. Opiskelijoita kannustetaan 


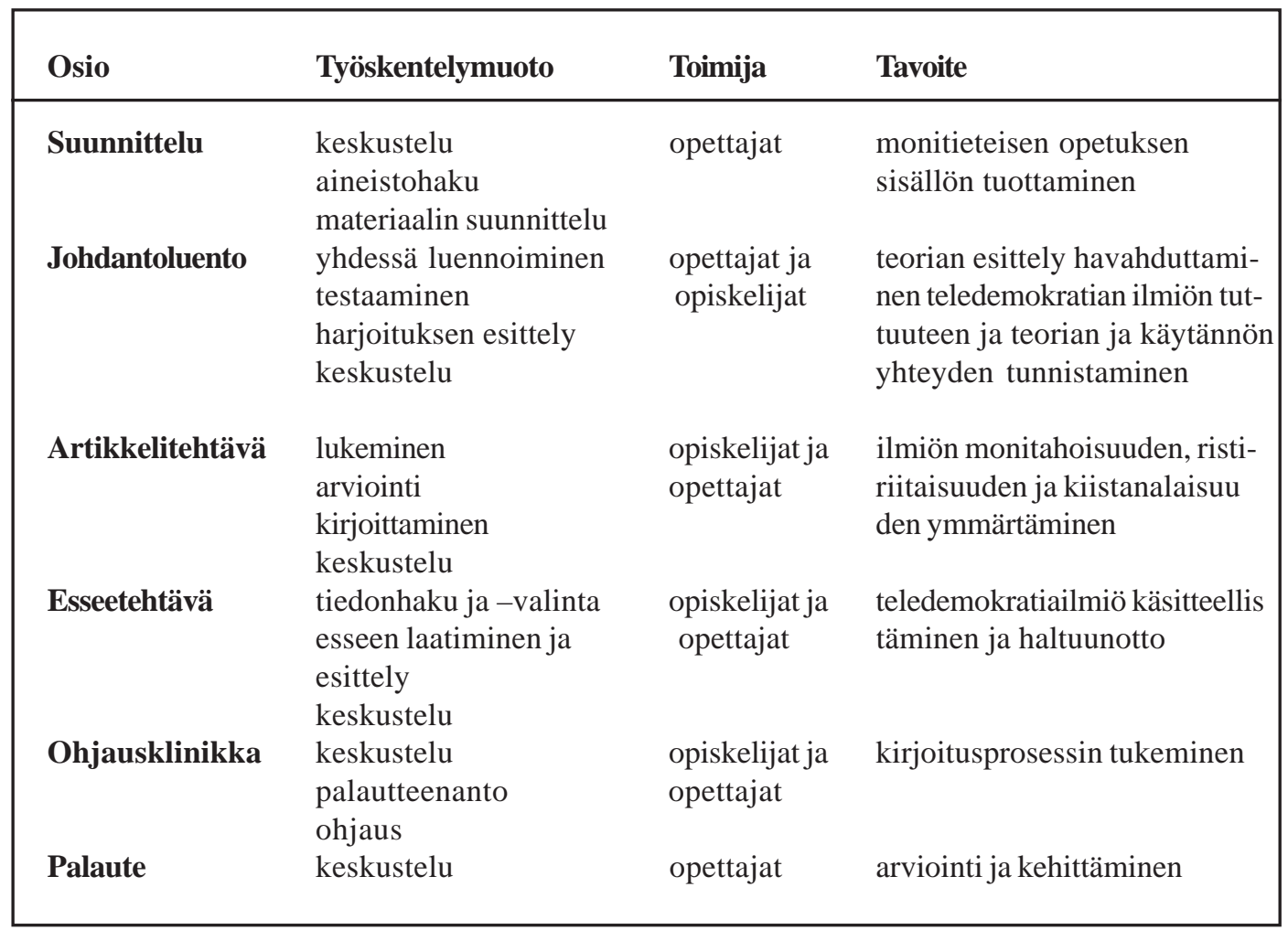

osoittamaan kohteita, joihin opittua voidaan soveltaa. Teeman esittelyssä harjoitellaan samalla tieteellisen keskustelun käytäntöjä ja tieteellistä argumentaatiota.

\section{AJATUKSIA MONITIETEISESTÄ OPETUKSESTA}

Y liopisto on instituutio, joka koostuu oppiaineiden ympärille rakennetuista laitoksista. Näillä on hyvinkin erilaisia oppimis, opetus- ja hallintokulttuureja ja oppiaineilla on verraten itsenäinen asema ja valta päättää toiminnastaan. Tehokkuusvaatimukset johtavat tilanteeseen, jossa yksiköt pikemminkin kilpailevat keskenään kuin tekevät yhteistyötä. Lokeroituminen ulottuu oppiaineiden sisältöjen lisäksi hallintoon. Monitieteisen opetuksen perusedellytys on yhteistyö. Se vaatii aktiivista yhteyksien luomista ja mahdollisuuksien kartoittamista, sillä yliopisto ei ole itsestään monitieteinen. Oppiainerajat ylittävä monitieteinen opetus vaatii sisältöjen ja toimintatapojen ennakkoluulotonta tarkastelua ja tarkastelijoita. Tutkintovaatimukset ovat rakentuneet oppiaineiden omista perinteistä käsin, eikä monitieteisellä opintojaksolla ole välttä- mättä paikkaa tutkintorakenteessa. Kuvaamiamme opintojaksoja on nyt järjestetty usean vuoden ajan. Opintojaksot ovat vakiinnuttaneet paikkansa opintotarjonnassa, monitieteisyys ja uudet aihevalinnat ovat alkaneet näkyä myös opinnäytetöissä ja opintojaksojen mallia sovelletaan yhteistyössä Jyväskylän yliopiston kanssa muun muassa Lapin yliopiston menetelmätieteiden laitoksella. Opintojaksojen pohjalla ollut tutkimusyhteistyö jatkuu edelleen.

Monitieteinen yhteistyö on nostanut käytännössä esiin myös yliopiston hallinnollis-organisatoriset rajat. Vaikuttaa siltä, että monitieteinen opetus ei niinkään pohjaa organisatorisiin rakenteisiin, kuten tiedekuntiin ja laitoksiin, vaan yksittäisten opettajien verkostoitumiseen opetusorganisaation sisällä ja haluun kehittää opetusta. Argumentaation ja retoriikan perusteet on Jyväskylän yliopistossa ensimmäinen tämänkokoinen hanke, jonka useat laitokset järjestävät yhdessä ja jonka hallinnolliset kustannukset jaetaan osallistuvien laitosten kesken. Käytännössä pienen rahasumman jyvittäminen ja siirtäminen laitosten välillä on osoittautunut yllättävän työlääksi ja montaa henkilöä työllistäväksi. Opettajan arkisena työnä monitieteisyys edellyttää avoi- 
muutta ja valmiutta sekä suunnitella että opettaa yhteistyössä muiden opettajien kanssa. Monitieteinen opetus vaatii opettajilta vaivannäköä sekä sieto- ja heittäytymiskykyä tilanteeseen, jossa opettajana ei pidäkään kaikkia lankoja käsissään vastatessaan mahdollisesti vain yhdestä opintojakson osiosta. Opiskelijoille ja opettajille luodaan tämänkaltaisella toiminnalla kuitenkin luontevia poikkitieteellisiä kohtaamistilanteita ja sitä kautta mahdollisuuksia muiden tieteenalojen ja niiden opetuskulttuurien tuntemiseen.

Eri tieteenalan opiskelijoille järjestettävällä opintojaksolla on huomioitava hyvinkin erilaiset oppimis-, opetus- ja hallinnolliset kulttuurit niin osallistuvien opettajien kuin opiskelijoiden näkökulmasta. Erityisesti suunnittelua vaatii yhteisen sisällön muokkaaminen sellaiseen muotoon, että eri tieteenalat voivat laajentaa ja soveltaa sisältöjä opetussuunnitelmiinsa. Toisaalta monitieteisen opintojakson etu on se, että tieteenalalle erityinen lähestymistapa voidaan jakaa muiden kanssa ja näin syventää aiheen käsittelyä. Edellä kuvattujen opintojaksojen suunnittelussa on panostettu opintojaksojen oppiainekohtaiseen räätälöitävyyteen, jolloin opintojakso voidaan joustavasti sijoittaa tutkintoon opiskelijan pääaineen ja opintojen vaiheen mukaan. Käytännössä opintojakson opettajien on sovitettava yhteen aikataulut suhteessa muihin kursseihin ja yli 10 opettajan omiin aikatauluihin.

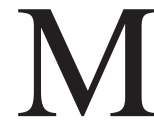
onitieteisen opetuksen näkökulmasta oppiaineiden eri luonteet ovat merkitseviä; monialaisten oppialojen opettajat ja opiskelijat ovat kasvaneet monitieteisessä toimintaympäristössä, perustieteellisessä ympäristössä monitieteisyys saattaa olla vierasta. Pääaineen ajattelumallit omaksutaan melko nopeasti, mikä ohjaa huomion suuntautumista asioihin, jotka muiden oppiaineiden näkökulmasta eivät näyttäydy merkityksellisinä. Opetus- ja keskustelukäytännöt vaihtelevat niin ikään oppiaineittain; toiminnalliset opiskelumenetelmät ovat luontevampia joissakin aineissa, kun taas vuorovaikutteiset menetelmät ovat vahvemmin esillä joissakin aineissa. Monipuolisten opetusmenetelmien avulla pyritään myös tukemaan erilaisia oppimistapoja. Monipuolisillakaan opetusmenetelmillä ei kuitenkaan voida korvata opiskelijan omaa aktiivisuutta oppimisessaan.

Tutkimus voi liittyä opetukseen eri tavoin. Löyhimmillään monitieteiseksi opetukseksi voi- daan kutsua esimerkiksi seminaaria, jossa eri alojen edustajat kokoontuvat saman teeman ympärille. Vahvimmillaan monitieteisessä opetuksessa voidaan hyödyntää monitieteistä tutkimusta. Jos sitä ei ole tarjolla, opettajan on tutkittava tai koostettava itse tai opiskelijoiden kanssa monitieteinen näkökulma. Mielestämme monitieteisen opetuksen kehitystyössä korostuvat selkeästi opettajien yhteistyö ja uudet toimintamallit. Näiden kahden opintojakson onnistumisen perustekijä lienee ollut se, että käytännön järjestämisestä vastaavat opettajat tuntevat toisensa ja tekevät tutkimusyhteistyötä. Kehittämistyö etenee havaintojemme mukaan nimenomaan ihmisten kautta, mutta organisaation ehdoilla. Opetuksen järjestämiseen sitoutuvat opettajat tekevät opintojaksosta elävän sekä tarpeisiin ja tilanteisiin reagoivan. Tämä vahvuus voi kääntyä helposti heikkoudeksi, jos yhteistyössä mukana ollut opettaja ei jatkossa olisi käytettävissä. Monitieteinen opetusyhteistyö on ollut erittäin aikaa vievää mutta palkitsevaa. Yliopistolla on kaksi perustehtävää: tutkimus ja opetus - tässä järjestyksessä. Omien kokemuksiemme mukaan opetuksen kehittäjien on mielekästä, jos ei peräti välttämätöntä yhdistää nämä perustehtävät siten, että ne tukevat opettajien omaa kehittymistä ja oppimista.

Monitieteistä opetusta voidaan tarkastella sisältöjen, menetelmien ja rakenteen näkökulmasta. Argumentaatio ja teledemokratia ovat monitieteisen tutkimuksen kohteita, sillä monitahoisen ilmiön haltuun saaminen edellyttää useita tieteitä ja menetelmiä. Tällöin on luontevaa järjestää monitieteistä opetusta. Näillä kursseilla opettajien yhteistoiminta on perusta monitieteiselle opetukselle. Suunnittelussa otetaan huomioon oppiainekohtaiset ja yhteiset ainekset, tarpeet ja tavoitteet sekä sovitetaan ne yhteen. Näillä kursseilla substanssit ovat näennäisesti riittävän jokapäiväisiä, jotta niitä voidaan lähestyä useasta ja vieraammastakin näkökulmasta. Toisaalta kyse on teledemokratian ja argumentaation ilmiöstä, eikä tällainen lähestymistapa ole hedelmällinen lähestymistapa minkä tahansa ilmiön käsitteellistämiseen. On aikalisän paikka, kun mietitään tuoko monitieteisyys lisäarvoa opetukseen.

\section{LÄHTEET}

Becker, T. \& C. Slaton C. (2000) The future of teledemocracy. Westport: Praeger.

Fishkin, J. (1991) Democracy and deliberation. 
New Haven: Yale University Press.

Hagen, M. (1997) A typology of electronic democracy. Saatavissa on-line muodossa osoitteessa: http://www.uni-giessen.de/fb03/vinci/ labore/netz/hag_en.htm. Viitattu 14.1.2004.

Life as Learning Programme Memorandum (2001) Academy of Finland, Research Council for Culture and Society. Saatavissa on-line muodossa osoitteessa: http://www.aka.fi/ . Viitattu 17.6.2004.

Malinen, A. (2000). Towards the essence of adult experiential learning: a reading of the theories of Knowles, Kolb, Mezirow, Revans and Schön. Jyväskylän yliopisto.

Masuda, Y. (1981) The information society as post-industrial society. Tokyo: World Future Society.

Rogoff, B. (1990) Apprenticeship in thinking. New York: Oxford University Press.

Vygotskij, L. (1978) Mind in society: the development of higher psychological processes. Cambridge: Harward University Press.

Watson, R., S. Akselsen, B. Evjemo, \& N. Aarsæther (1999). Teledemocracy in local government. Communications of the ACM
42(12): 58-63.

Watson, R. \& B. Mundy (2001) A strategic perspective of electronic democracy. Communications of the ACM 44(1): 27-30.

Wilhelm, A. (2000) Democracy in the digital age. New York: Routledge.

\section{VIITTEET}

1. van Eemeren, Grootendorst \& Henkemansin toimittama teos Fundamentals of Argumentation Theory (1996) on argumentaatioteorian perusteos. Se sisältää argumentaatioteorian lyhyen historian ja uusien merkittävien suuntausten esittelyn ja erittäin kattavan bibliografian. KakkuriKnuuttilan Argumentti ja kritiikki (1998) on suomenkielinen argumentaatioteorian perusoppikirja.

2. Aarnio, Jäkälä, Hoffrén \& Isotaluksen artikkeli Poliittisen toiminnan uusilla foorumeilla (Tiedotustutkimus 2001, 24:3, 4-18) käsittelee teledemokratian tavoitteita ja haasteita.

\section{KIITOKSET}

Artikkelin kirjoittajat kiittävät lämpimästi lehtori, KTT Anita Malista ja fil. yo. Maria Kollmannia kirjoitusprosessin aikaisista kommenteista. 